3500 square miles, I have so far received 250 records in which the time is given, from the outer sound-area of about 5700 square miles 223 records (including 122 from Norfolk and fifty-six from Lincolnshire), and from the zone of silence of about 4500 square miles only one, and that one close to the sea. The greatest distance to which the sound-waves penetrated is about I2 I miles.

A remarkable feature about these records is that, though all of them have been sent in reply to my newspaper letters (and therefore sent as it were at random), they are almost as thickly grouped near the boundaries as near the centres of the two areas. There is none of that increasing sparseness of records near the boundary which is so characteristic of earthquake investigations. It would seem as if the boundary were determined, not by the sound-vibrations becoming inaudible, but by the absence of soundvibrations from the area beyond. It may be of interest to add that, at a large number of places, pheasants showed signs of alarm, as they did during the North Sea battle of January 24, I915.

May I, in conclusion, state how glad I should be to receive (address: 16 Manor Road, Edgbaston, Birningham) further acoounts of the explosion, and especially negative records? Observations on the direction of the surface and upper winds would be of great value. Charles Davison.

\section{RECENT PAPERS ON PARASITES.}

$\mathrm{O}$

$\mathrm{NE}$ of the most notorious of protozoan parasites at the present time is the microsporidian Nosema apis, which, since the well-known researches of Drs. H. B. Fantham and Annie Porter in 1912, has been generally regarded as the cause of "Isle of Wight disease " in hive-bees. In the Proceedings of the Royal Physical Society of Edinburgh (vol. xx., part r) two papers have lately appeared in which this conclusion is called in question-one by John Anderson, the other by the same author in collaboration with Dr. John Rennie. Stress is laid on the possibility of bees heavily infested with Nosema showing no symptoms of the disease; this condition was recognised by Fantham and Porter, who attributed it to immunity in certain strains, and directed attention to the danger caused to other bees by such "carriers." On the other hand, an epidemic of disease among bees on Deeside with all the characteristic "Isle of Wight" symptoms appeared to be unaccompanied by any trace of Nosema in the affected insects. It may, of course, be retorted that the parasites were present in inconspicuous stages and in relatively small numbers, as Fantham and Porter concluded to be the case in similar instances observed by them. Anderson and Rennie, however, "are unable to recognise any causal relation between the presence of this parasite and the disease," though it "may be a contributing weakening factor favouring in certain cases the development of the disease." It may be doubted if the authors sufficiently recognise the possibly deadly effects, on certain strains of bees; of parasites so few in number as to escape observation.

Students of the Sporozoa will read with more than usual interest Dr. Howard Crawley's paper entitled "The Sexual Evolution of Sarcocystis muris" (Proc. Acad. Nat. Sci., Philadelphia, lxviii., part I), in which the early development of the parasites in the intestinal cells of the mouse is described with numerous figures. The spores swallowed by the mouse reach the hinder-end of the small intestine within an hour and invade the epithelial cells. Some spores then undergo a great enlargement of the nucleus and degeneration of the cytoplasm, while others remain much as when they entered the cell, becoming, however, relatively. shorter and broader than the original spores; the author regards the former as male and the latter as female gametes. From six to fifteen hours after penetration chromatin granules separate from the nucleus and are absorbed by the protoplasm; this process is interpreted as maturation. "Finally, in the eighteen-hour stage, macrogametes may be found which in some cases show minute, thread-like bodies upon their surfaces, and in others contain within their substances small, solid chromatic bodies, one in each case. These appearances are regarded as warranting the interpretation that fertilisation takes place." Dr. Crawley's work goes far to establish the existence of a sexual phase in the sarcosporidian life-cycle, but it appears to fall short of demonstration.

In the Proceedings of the U.S. National Museum (vol. 1., No. 2131) an important systematic paper on "Nematode Parasites of the Rodentia and Hyracoidea" has been published by Maurice C. Hall. Most of the species described are illustrated by clear structural figures, and there are diagnoses of the various classificatory groups, so that the paper will be of much value to students. In the class-diagnosis of the Nematoda it is rather surprising to find no stress laid on the entirely epithelial nature of the intestinal wall or on the anomalous character of the body-cavity.

Several papers on parasites are to be found in the lately issued third and fourth reports of the director of veterinary research for the South African Union Department of Agriculture (Pretoria, I9I6). Sir A. Theiler and W. Robertson describe the life-history of Trichostrongylus douglasi, a nematode parasite of the ostrich, somewhat unfortunately called a "wireworm." The four larval stages are carefully distinguished, and it is shown that the young worm can survive and become mature in the bird's stomach only when swallowed in its late second stage. No evidence that the worms ever enter through the skin could be obtained. Dr. F. Veglia contributes an exhaustive paper on "The Anatomy and Life-history of Haemonchus contortus," a well-known strongylid parasite of the stomach in ruminants; in this memoir a number of structural and bionomic details are recorded. The photographs and careful drawings illustrating these reports are reproduced in excellent style; it is all the more disappointing to find that for the letterpress of these valuable zoological papers a cheap contract method has apparently been adopted by the South African Government which recalls the worst traditions of our Home Stationery Office.

\section{THE LOUTREUIL FUND.}

\section{GRANTS FOR SCIENTIFIC WORK.}

IN the Comptes rendus of the Paris Academy of Sciences for November 27 is given the report of the council of the Loutreuil Foundation. The grants allotted are divided into three groups, as follows :-

I. Establishments Mentioned by the Testator.(I) Museum of Natural History. 2000 francs to Prof. Louis Roule for the continuation of his researches on the migratory fishes of French marine and fresh waters, the Salmonideæ in particular. ro,ooo francs for refitting the maritime laboratory of the Island of Tatihou at Saint-Vaast-La-Hougue. This laboratory has been used as a concentration camp since the outbreak of war, and considerable damage has been done. (2) The Collège de France. 700 francs to E. Gley to complete the frigorific installation for which an allocation was made last year. $435^{\circ}$ francs to Prof. Nageotte for the purchase of apparatus for pursuing his studies on the regeneration of nerves. 4000 francs to M. l'Abbé Rousselot for continuing and developing the experiments commenced by him on locating artillery by No. 2466, VOL. 98] 
sound. (3) Conseil Central des Observatoires. I5,000 francs to the Observatory of Paris for the improvement of astronomical instruments applied to the determination of time. I 500 francs to the Observatory of Marseilles for ensuring the publication of the Journal des Observateurs.. (4) Ecole Nationale Vétérinaire d'Alfort. 7000 francs to this school for the purchase of an apparatus for kinematographic registration and projection; this will be of great service in the study and demonstration of various movements in the normal or pathological state. (5) Ecole Nationale Vétérinaire de Lyon. 850 francs to Charles Porcher for the purchase of instruments to be used in his researches on milk. Soo francs to François Maignon for the purchase of a balance and a small hydraulic press, to be used in his researches on nutrition. (6) Ecole Nationale Vétérinaire de Toulouse. 5000 francs to this school for a radiological installation to be used in the diagnosis of diseases of animals.

II. Establishments Nominated to the Committee by the President of the Academy.-(I) Conservatoire des Arts et Métiers. 4000 francs to Louis Blaringhem for the creation of a typical collection for the determination and classification of the woods used in the aeronautic industry. 5000 francs conditionally to James Dantzer for the creation of a laboratory for the testing of textiles, fibres, and tissues under the express condition that the Union des Syndicats Patronaux de 1'Industrie Textile contributes the same amount. Ecole Nationale Supérieure des Mines. Io,00o francs to this school for completing the laboratory installation, especially as regards motive power. (3) Institut Catholique de Paris. 2000 francs to Henri Colin for the purchase of apparatus not usually found in botanical laboratories, to be used in his researches on the conditions of destruction of various bacilli. 2000 francs to Jules Hamonet for purchasing apparatus for determining the physical constants, particularly refractive indices, of the new substances he has discovered in the glycol group.

III. Various Direct Requests for Grants.To, oo francs to Jules Garçon for the preparation of a bibliography of bibliographers, a part to be used in making an inventory of the scientific periodicals contained in the libraries of Paris. 3000 francs to Guil. laume Bigourdan for the construction of an angle comparator for measuring the variation which the angular distance of two stars may show in a short interval of time. 3000 francs to Henri Bourget for his researches on astronomical photometry. 2000 francs to A. Col. son for continuing his researches on solutions. 7000 francs to Augustin Mesnager for improving the equipment of the laboratory for testing materials under his direction at the Ecole des Ponts et Chaussées. 2000 francs to Jules Glover for continuing his researches on telephony. 7000 francs to Louis Jobin to complete the publication of his studies relating to the material collected in the second Antarctic voyage of Jean Charcot. 5000 francs to the Société de Documentation Paléontologique. 2000 francs to J. M. R. Surcouf for assisting the publication of his work on horse-flies.

The total amount in grants is II 5,200 francs.

\section{THE U.S. NATIONAL RESEARCH COUNCIL.}

THE December, 1916, issue of the Proceedings of the U.S. National Academy of Sciences contains reports of meetings of the council on November I 3 and I4 last, and of the meetings of the Executive Committee of the council held during October and November. At these meetings several committees were ap. pointed to deal with specific questions. Among these may be mentioned that to confer with representatives of the National Canners' Association in the conduct

No. 2466 , VOL. 98$]$ of investigations on toxic elements in canned foods; that to co-operate with the Government Committee on Ocean Surveys and Ice Patrol; that on the utilisation of industrial research facilities for the national defence; that to consider the organisation of research in anthropological and sociological. sciences; and general committees (in addition to that on chemistry previously established) on mathematics, astronomy, physics, geology and palæontology, geography, botany, zoology and animal morphology, physiology, medicine, hygiene, agriculture, psychology, and anthropology.

At the meetings of the council in November several members gave addresses, one of which, on scientific research for national defence as illustrated by the problems of aeronautics, was by Lieut.-Col. G. O. Squier, and of this we print an abstract from the Proceedings of the National Academy.

Scientific Research for National Defence as Illustrated by the Problems of Aeronautics.

The following are some present problems connected with the development of military aviation and aerostation.

r. Aerodynamics.--(a) Continue the development of the mathematical theory to explain the aerodynamic phenomena recorded in the aerodynamical laboratories, and to forecast further results.

(b) Obtain solutions for the speed and direotion of flow of air about geometric and aenotechnic forms and develop experimental means to visualise or map the speed and direction of flow.

(c) Map the currents of the upper atmosphere which may be of most use in aerial navigation, and evolve simple practical rules for the guidance of pilots.

(d) Give fuller explanation of the phenomena of soaring, i.e. airplaning indefinitely without motive power.

(e) Develop equations and laws of comparison by which the behaviour of large aircraft may be more accurately foretold from tests of models. Apply further the principle of dynamical similarity.

$(f)$ Investigate more direct and effective methods of securing a lift or thrust in the air from the consump. tion of fuel.

(g) Complete theory of the air-screw.

2. Engine Problems Requiring Research.-(a) Fuel. Possibly the most far-reaching problem is fuel. A fuel that will carry more power into an engine per unit volume will be a direct gain.

Attempts have been made to combine alcohol, gaso. lene, acetylene, picric acid, ether, and other hydrocarbons with the above object in view. Questionable results have followed. There has been an increase of power, but nothing so far commercially or practically useful.

This question must be studied with the greatest of care and from a truly research point of view.

(b) Solid fuel. Solid fuels that can be converted into liquid in small quantities just prior to use are desirable for military aviation. In case of accident from shot or shock, leakage of liquid fuel is a danger. Solid fuel could be carried in quantity with less danger.

(c) Engine cooling. The problem of radiation is important. If some substance could be found that would circulate through the cooling system, at higher temperatures than water, it is probable that greater engine efficiencies would result. Oils, salt waters, and other materials have been tried with indifferent success.

(d) Liquid-fuel pipes. Tubing that will resist vibration (causing rupture) is desired. An dil and gasolene proof rubber tubing is reported as used in Europe. This development is highly important, not only for tubing, but for containers in which to carry liquid fuel. Some sort of fabric and rubber tank that would 